ШУЛЬЦ С.Л.

д.е.н., професор,

завідувач відділу регіональної економічної політики

ДУ «Інститут регіональних досліджень ім. М.І. Долішнього НАН Украӥни»

вул. Козельнииька, 4, м. Львів, Україна, 79026

swetshul@i.ua

ORCID: 0000-0002-5603-5603

\title{
ЛУЦКІВ О.М.
}

к.е.н., старший науковий співробітник,

с.н.с. відділу регіональної економічної політики

ДУ «Інститут регіональних досліджень ім. М.І. Долішнього НАН України»

вул. Козельницька, 4, м. Львів, Україна, 79026

lutolen@i.ua

ORCID: 0000-0002-8919-6761

\section{ІННОВАЦІЙНА СКЛАДОВА ІНКЛЮЗИВНОЇ МОДЕЛІ ЕКОНОМІЧНОГО ЗРОСТАННЯ КРАЇН-ЧЛЕНІВ ЄС}

\begin{abstract}
Актуальність. Нова інклюзивна модель соціально-економічного розвитку орієнтована з одного боку на забезпечення добробуту населення, сприяння соиіальної згуртованості та повагу до прав людини, з іншого стимулює інновації та перехід до вуглецево-нейтральної, стійкої та цциркулярна економіка з дотриманням прав людини на всіх етапах ланцюжка створення вартості. Інклюзивна модель економіки передбачає залучення в процес розвитку всіх секторів економіки, і високотехнологічних зокрема. Для досягнення інклюзивної моделі економічного зростання ЄЕ має значний потенціал завдяки можливостям, щзо надаються, інноваціями. Інновації, з одного боку забезпечують підвищення конкурентоспроможності, продуктивності праці та ефективності використання ресурсів території, з іншого - створення нових робочих місць, щзо сприяє розвитку людини, підвищення ії добробуту, зниженню рівня безробіття, бідності і нерівності.

Мета та завдання. Аналіз сучасного сучасного стану та тенденцій розвитку інноваційної діяльності в краӥнах-членах $€ C$.

Результати. В статті основна увага зосереджена на дослідженні інноваційної складової інклюзивної моделі розвитку ЄС. Проаналізовано особливості та тенденцій інноваційного розвитку країн-членів ЄС. Зокрема, зміну тендениій інновачійного розвитку крайн-членів СС за Глобальним індексом інновацій у 2016 та 2018 рр. Особливості та тендениії розвитку інноваційної сфери крайн-членів СС $i$ зайнятості у галузях промисловості з високими та середніми технологіями та наукоємних секторах обслуговування. Проаналізовано стан зовнішньої торгівлі: структуру та обсяги експорту високотехнологічної продукції за 2010-2018 pp.

Висновки. Результати проведено дослідження засвідчують про нарощення інноваційного потенціалу країн-членів СС впродовж 2010, 2019 рр. Дещо нижчий рівень інноваційного розвитку прослідковується в нових краӥнах-членах ЄС. Краӥни-члени ЄС і надалі займають високі рейтингові позиції за індексом інноваційного розвитку у світі та посилюють свої позииії у світі.

Ключові слова: інновації, інклюзивна модель, глобальний індекс, інноваційна сфера, високотехнологічна продукиія.
\end{abstract}

\section{SHULTS S.L.}

Dr.Sci. (Econ), Prof,

Head of the Departament of regional economic policy

SI «The Institute of Regional Research named after M.I. Dolishniy of the NAS of Ukraine»

street Kozelnytska, 4, Lviv, Ukraina, 79026

swetshul@i.ua

ORCID: 0000-0002-5603-5603

LUTSKIV O.M.

Ph.D. (Econ.), Sen.Res.

Senior Researcher of the Departament of regional economic policy 


\section{INNOVATIVE COMPONENT OF THE INCLUSIVE MODEL OF ECONOMIC GROWTH OF EU MEMBER COUNTRIES}

Topicality. The new inclusive model of socio-economic development is focused on the well-being of the population, promoting social cohesion and respect for human rights, as well as stimulates innovation and the transition to a carbon-neutral, sustainable and circular economy with human rights at all stages of a value chain. The inclusive model of the economy involves the development of all sectors of the economy and high-tech in particular. The EU has significant potential to achieve an inclusive model of economic growth through the opportunities provided by innovation. Innovations, on the one hand, increase competitiveness, labor productivity, and resource efficiency, on the other, create new jobs that promote human development, increase welfare, reduce unemployment, poverty, and inequality.

Aim and tasks. Analysis of the current state and trends of innovation in EU member states.

Research results. The article focuses on the study of the innovative component of the inclusive model of EU development. Peculiarities and tendencies of innovative development of EU member states are analyzed. In particular, the change of trends in innovative development of EU member states according to the Global Innovation Index in 2016 and 2018. Features and trends of innovation in EU member states and employment in industries with high and medium technologies and knowledge-intensive service sectors are described. The state of foreign trade is analyzed, such as the structure and volumes of exports of high-tech products for 2010-2018.

Conclusion. The results of the study show an increase in the innovation potential of EU member states during 2010, 2019. A slightly lower level of innovation development is observed in the new EU member states. EU member states continue to rank high in the world innovation index and strengthen their position in the world.

Keywords: innovations, inclusive model, global index, innovation sphere, high-tech products.

Постановка проблеми та їі зв'язок з важливими науковими та практичними завданнями. Сьогодні інклюзивність стає одним з провідних параметрів розвитку економіки СС. Нова інклюзивна модель соціально-економічного розвитку орієнтована з одного боку на забезпечення добробуту населення, сприяння соціальної згуртованості та повагу до прав людини, 3 іншого - стимулює інновації та перехід до вуглецево-нейтральної, стійкої та циркулярна економіка 3 дотриманням прав людини на всіх етапах ланцюжка створення вартості. Інклюзивна модель економіки передбачає залучення в процес розвитку всіх секторів економіки, і високотехнологічних зокрема. Для досягнення інклюзивної моделі економічного зростання ЄЄ має значний потенціал завдяки можливостям, що надаються, інноваціями. Інновації, з одного боку забезпечують підвищення конкурентоспроможності, продуктивності праці та ефективності використання ресурсів території, з іншого - створення нових робочих місць, що сприяє розвитку людини, підвищення іiі добробуту, зниженню рівня безробіття, бідності і нерівності. 3 огляду на те тематика дослідження, яка присвячена дослідженню інноваційної складової інклюзивного розвитку країн-членів ЄС є актуальною і своєчасною.

Аналіз останніх публікацій по проблемі. В останні десятиліття проблематика ролі наукових дослідженнь та інновацій у формуванні нової моделі розвитку економіки постійно перебуває в центрі уваги економічних стратегій та Рамкових програмах СС (Лісабонська стратегія, «ннноваційної стратегії», Рамкова програми конкурентоспроможності й інновацій, Стратегія «Свропа-2020» тощо). Дослідження сутності та особливостей формування інклюзивного розвитку економіки перебувають в центрі уваги багатьох міжнародних інституцій, серед яких: Організація економічного співробітництва та розвитку (ОЕСР), Програма розвитку ООН (ПРООН), Європейська комісія, Міжнародний валютний фонд (МВФ), Всесвітній економічний форум (ВЕФ), Світовий банк, Свропейський банк реконструкції та розвитку, Міжнародний центр політики інклюзивного зростання тощо. Засади теорії інклюзивного розвитку закладені дослідженнями переважно закордонних вчених: Д. Аджемоглу, 3. Бедоса, С. Голандера, Д. Робінсона, Е. Райнерта, Дж. Подеста та багато інших. Дослідженню ролі і значенню інновацій в процесах інклюзивного розвитку також відводиться чільне місць в працях, як вітчизняних так і зарубіжних економістів, серед яких: Л. Антонюка, О. Амоші, Ю. Бажала, А. Гальчинського, С. Ілляшенка, О. Прогнімака, І. Тараненко, Л. Федулової, Р. Коуза, Д. Львова, Р. Нельсона, Х. Фрімена, Й. Шумпетера та багатьох інших.

Виділення невирішених раніше частин загальної проблеми. Незважаючи на значну кількість досліджень присвячених даній проблематиці питання вибору, функціонування i 
трансформації моделі економічного розвитку і надалі є важливими для всіх без винятку європейських країн. Визначальну роль у формуванні інклюзивної моделі економічного зростання відіграють інновації та розвиток високотехнологічних галузей. Однак, не зважаючи на це в країнах-членах ЄС спостерігається значний розрив в рівнях інноваційного розвитку незважаючи на те, що частка зайнятих у галузях промисловості з високими та середніми технологіями та наукоємних секторах обслуговування. 3 огляду на це, дослідження питання інноваційної складової інклюзивної моделі економічного зростання є актуальним та потребує подальшого дослідження.

Формулювання цілей дослідження (постановка завдання). Аналіз сучасного сучасного стану та тенденцій розвитку інноваційної діяльності в країнах-членах ЄС.

Виклад основних результатів та їх обгрунтування. Для оцінки стану інноваційного розвитку у світі використовують ряд показників. Серед них: Глобальний індекс інновацій (Global Innovation Index), Індекс інноваційного розвитку агентства Bloomberg (Bloomberg Innovation Index), Глобальний індекс конкурентоспроможності (Global Competitiveness Index), Інноваційний індекс Свропейського інноваційного табло (Innovation Union Scoreboard), Глобальний індекс конкурентоспроможності талантів (Global Talent Competitiveness Index), Оцінка готовності до майбутнього виробництва (Readiness for the Future of Production Assessment) тощо.

Згідно 3 доповіддю «Глобальний індекс інновацій», підготовленою спільно Корнуельським університетом, школою бізнесу INSEAD і Всесвітньою організацією інтелектуальної власності за 2010 та 2019 рр. країни-члени СС посилили свої позиції у світі за цим показником. Так, якщо у 2010 році серед краї-членів СС до десяти найбільш інноваційних країн світу увійшли лише 3 країни Швеція (2 місце), Фінляндія (5) та Данія (6), то у 2019 році їх кількість зросла до 5. До них долучились Великобританія (5) та Німеччина (9). Відповідно Фінляндія і Данія втратили в рейтингу по одній позиції. Лідерство Швеція за рівнем інноваційного розвитку в значній мірі зумовлено ефективною політикою Міністерства підприємств та інновацій яке діє в країні. Потрапити Німеччині до 10 лідерів за рівнем інновацій вдалося завдяки зростанню концентрації високотехнологічних компаній та високому рівню інновацій в автомобільному секторі. Близько третини усіх витрат на дослідження і розробки в країні припадає саме на автомобільну промисловість. Значну стимулюючу роль у сприянні інноваційному розвитку має також і Федеральне міністерство економіки. 3 іншого боку, на сьогодні основною проблемою в Німеччині є нестача кваліфікованої робочої сили. 3 огляду на те, уряд цієї країни значну увагу приділяє залученню молодих фахівців 3-за кордону. Для цього в країні створені всі умови для отримання якісної вищої освіти. Так, освіта в Німеччині для іноземців безкоштовно [1].

Глобальний індекс інновацій розраховується на основі семи підіндексів: креативність, знання й результати наукових досліджень, бізнес-досвід, ринкові показники, інфраструктура, людський капітал і дослідження, інституції. Дані рис. 1. свідчать, що майже всі країни-члени ЄС посилили свої позиції за цим показником. Виключення становлять лише Мальта та Угорщина, які перемістились впродовж аналізованого періоду часу відповідно: з 16 на 27 та 325 на 33 місце [1].

За період 2000-2018 рр. приріст питомої ваги інноваційної сфери в загальному обсязі доданої вартості в економіці ЄС становив 0,5\%. Понад 50\% доданої вартості в Європі було вироблено у високотехнологічних секторах економіки.

Згідно 3 інформацією «Global Insight World Industry Service database» світовий ринок високотехнологічної продукції з кінця XX ст. мав тенденцію до значного зростання, а вже на початку XXI ст. відбувся значний приріст торгівлі високотехнологічними товарами в країнах ЄС [2]. До високотехнологічних галузей сьогодні відносять: аерокосмічну, фармацевтичну галузі; виробництво комп'ютерної, офісної техніки та створення програмного забезпечення; надання консалтингових послуг з цифрової трансформації бізнесу та підтримку інформаційно-комунікаційної інфраструктури; виробництво електроніки та телекомунікаційного обладнання; виробництво медичної, високоточної та оптичної техніки [3].

Однак, незважаючи на міцні конкурентні позиції у низці інноваційних секторів економіки, таких як квантові обчислення і телекомунікації, Європа відстає від США і Японії за часткою зайнятих в наукомістких галузях, де сконцентровано близько $14 \%$ робочої сили, в той час як в США $\mathrm{i}$ Японії - 16-17\% [4].

Досить висока частка високотехнологічного експорту Мальти пояснюється перенесенням після 2014 року деякими європейськими компаніями своїх філії з азійських країн до Мальти, пояснюючи це окрім близькості розташування знанням мальтійцями англійської мови, передбачуваністю та стабільністю країни. Високі показники Люксембургу зумовлені високою репутацією 
високотехнологічної продукції, що виробляється в країні на світовому ринку, податковою політикою та знання місцевими працівниками декількох мов [8].

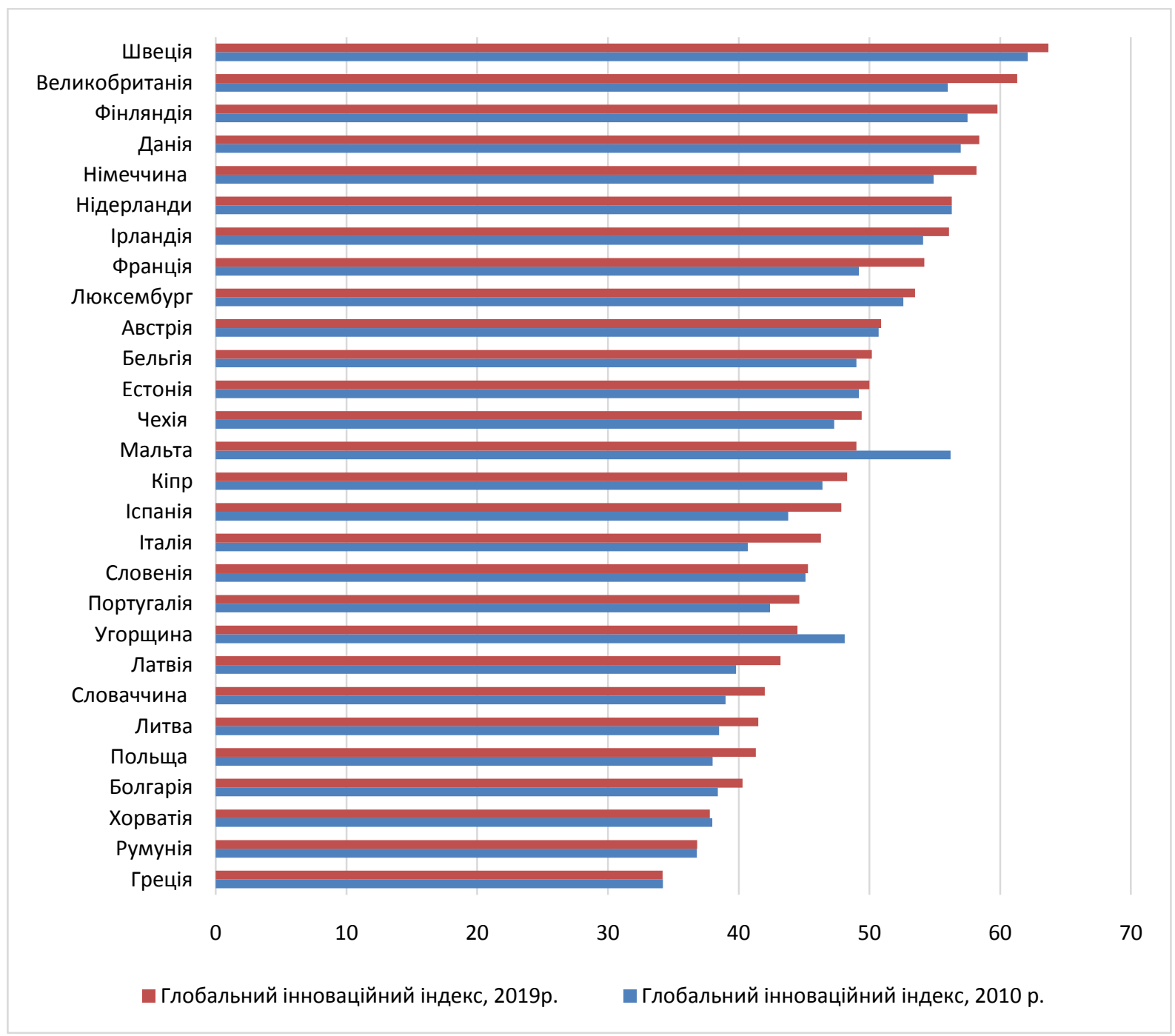

*Розраховано за даними: [1]

Рис. 1. Глобальний індекс інновацій у 2010, 2019 pp. ${ }^{2}$

Світовий досвід економічно та технологічно розвинутих країн світу свідчить, що вирішальне значення для розвитку високотехнологічної економіки має фінансування освіти та науки, оскільки інвестиції в людський капітал є основою нарощення інноваційного потенціалу.

Активізація розвитку інноваційної сфери в країнах-членах ЄС зумовлена в значній мірі тим, що вони приділяють значну увагу налагодженню взаємодії держави і суспільства, створюють умови, що сприятимуть розвитку науки та освіти, наукових розробок і досліджень та, безумовно, значеною $\epsilon$ і фінансова підтримка інноваційного розвитку з боку держави.

До країн-членів $\mathrm{CC}$, де фіксують найвищу частку зайнятих у галузях промисловості з високими та середніми технологіями та наукоємних секторах обслуговування належать країни 3 найвищою часткою зайнятості у промисловості (рис. 2).

Чотири країни - Німеччина, Великобританія, Італія та Польща, разом становлять близько 53\% високотехнологічного сектору в ЄС-28. Так, у Великобританії зафіксована найбільша кількість підприємств у секторі високотехнологічних інформаційних послуг (180 257 підприємств), потім йдуть Франція (141 647) та Німеччина (112 570) [5].

Високотехнологічна продукція стає важливою категорією світового та європейського експорту. Згідно зі Стандартною міжнародною торговельною класифікацією (Standard International Trade

${ }^{2}$ Мальту до розрахунку Global Innovation Index включено з 2012 року 
Classification, Rev.3 (SITC)) до високотехнологічних експортних товарів належать: авіакосмічна продукція; озброєння; комп'ютери та офісні машини; електронна та телекомунікаційна апаратура; фармацевтична продукція; прилади для дослідження; електричні машини; неелектричні машини; хімічні продукти [6].

Аналізуючи розподіл високотехнологічного експорту серед європейських країн спостерігаємо його значно меншу роль у загальному обсязі національного експорту в колишніх соціалістичних країнах та південноєвропейських - Греції, Іспанії, Португалії, Італії (рис. 3). Однак в усіх, окрім Румунії, країнах колишніх соціалістичних країн спостерігається зростання цього показника, що пояснюється розміщенням на території цих країн окремих циклів високотехнологічних виробництв транснаціональних корпорацій.

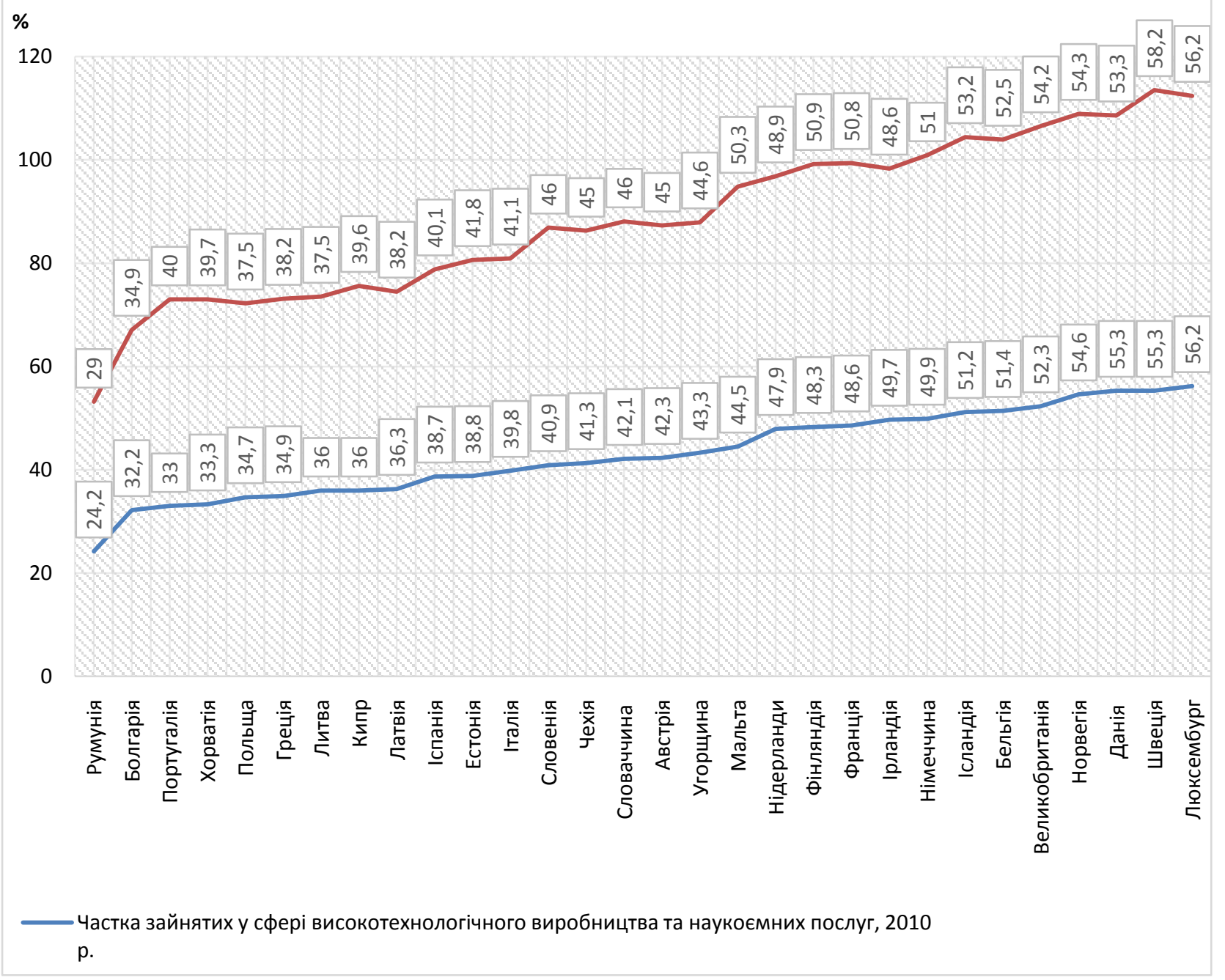

Рис. 2. Частка зайнятих у галузях промисловості з високими та середніми технологіями та наукоємних секторах обслуговування в країнах-членах ЄС, 2010, 2018 pp.

*Розраховано за даними: [5]

У 2018 році 18\% усього експорту Євросоюзу - це високотехнологічна продукція. США були основним партнером 3 експорту ЄC $(26 \%$ експорту $Є C)$. Щорічний приріст експорту високотехнологічної продукції становить 6\%. Серед продукції основними $\epsilon$ аєрокосмічна, фармацевтика, електроніка-телекомунікації та наукові інструменти. За останні десять років відбулось збільшення вартості експорту $\mathrm{CC}$, а найбільший приріст зафіксовано в аптечній та аерокосмічній сферах. Імпорт високотехнологічної продукції досягає 19\% загального імпорту СС. $38 \%$ високотехнологічної продукції, що імпортується до ЄС, входить до групи товарів «електронікателекомунікації». Спостерігається тенденція до зростання експорту фармацевтичної продукції та зниження частки комп'ютерного та офісного обладнання [7]. 


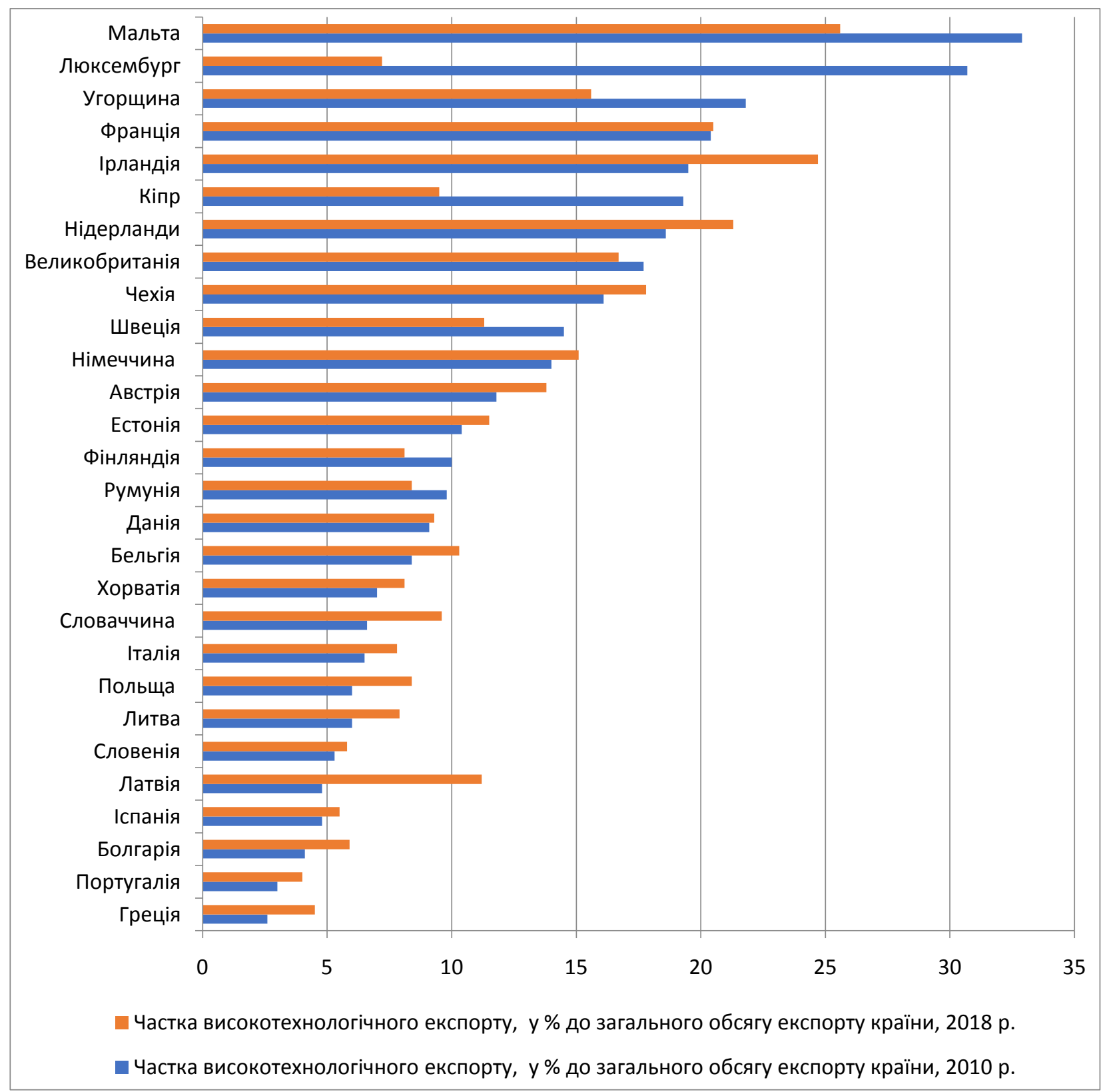

Рис. 3. Частка високотехнологічного експорту у структурі експорту країн-членів СС за 2010, 2018 pp. *Розраховано за даними: [7]

ЄС є одним з світових лідерів за показниками державних витрат на НДДКР і чисельності науковців. На ЄС припадає близько $23 \%$ (і $20 \%$ ) загального світового обсягу державних (і приватних) інвестицій в НДДКР, в той час на США і Китай - відповідно 21\% (i 28\%) і 16\% (i 24\%) [4].

Найбільші обсяги фінансування науки серед країн-членів ЄС спостерігаються у Швеції, Австрії, Данії, Німеччині, Фінляндії, Бельгії та Франції, а лідерами за часткою витрат державного бюджету на наукові дослідження є Німеччина, Естонія та Хорватія (рис. 4) [10]. Натомість країни Центральної і Східної Європи замикають цей рейтинговий список, хоча вони істотно підвищили інтенсивність інвестування в НДДКР протягом останнього десятиліття.

Слід відзначити також той факт, що у порівнянні з США, СС відстає за обсягами інвестицій в інформаційні та комунікаційні технології. Незважаючи на позитивну динаміку частка публікацій відкритого доступу, які сприяють дифузії знань і передового досвіду, залишається в країнах ЄС нижчими (30\%), ніж в США (35\%). Ще більше відставання спостерігається за кількістю спільних публікацій приватного і державного секторів, що відображає ступінь кооперації між ними - 30 публікацій у розрахунку на мільйон населення в Європі проти 63,4 в США [10]. 


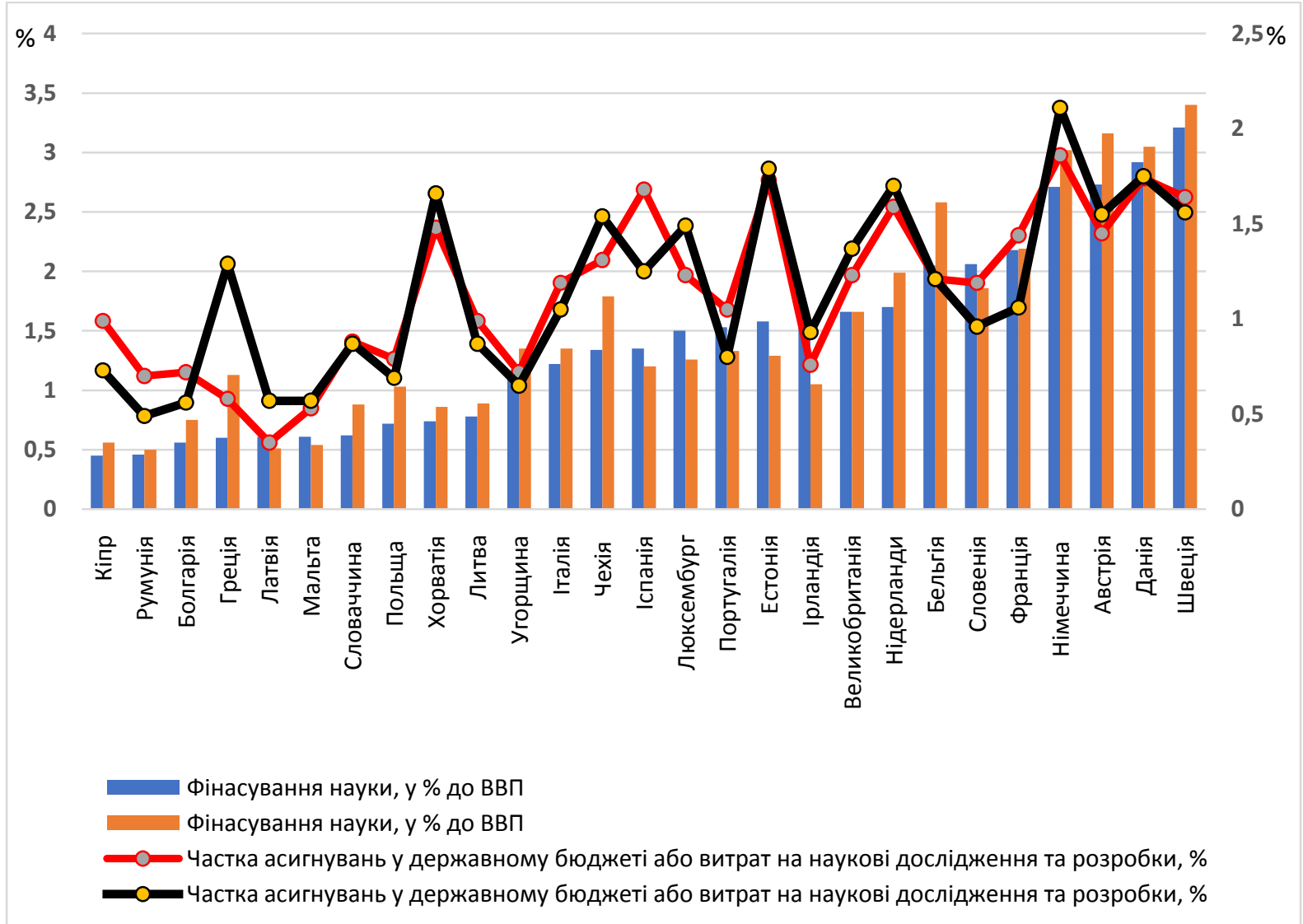

Рис. 4. Динаміка фінансування науки в країнах-членах ЄС за 2010, 2018 pp.

*Розраховано за даними: $[4 ; 10]$.

Ще однією важливою передумовою переходу економіки більшості країн світу до інклюзивної моделі є використання ефективних способів перетворення інноваційних технологій у прибутковий бізнес [11]. Одним $з$ таких способів $є$ розвиток кластерів, в яких відбуватиметься формування ланцюга «наука-інновації-виробництво». В країнах-членах СС сформовано та діють кластери за наступними напрямами [12]:

- електронні технології і зв'язок, інформатика (Швейцарія, Фінляндія);

- біотехнології і біоресурси (Нідерланди, Німеччина, Франція, Великобританія);

- фармацевтика і косметика (Данія, Швеція, Франція, Італія, Німеччина);

- агровиробництво і харчове виробництво (Фінляндія, Бельгія, Франція, Італія, Нідерланди);

- нафтогазовий комплекс та хімія (Швейцарія, Німеччина, Бельгія);

- машинобудування, електроніка (Нідерланди, Італія, Німеччина, Ірландія);

- охорона здоров'я (Фінляндія);

- $\quad$ легка промисловість (Австрія, Італія, Швеція, Данія, Фінляндія);

- лісовий комплекс (Фінляндія).

Для ефективного функціонування таких кластерів на національному рівні в країнах-членах СС створено умови для забезпечення поширення нових технологій у приватному секторі економіки. Основні зусилля урядів цих країн сьогодні спрямовані на розвиток технологій нового покоління, а також стимулювання інвестицій і ділової активності у пріоритетних видах економічної діяльності п'ятого та шостого технологічного укладів шляхом зниження податків і зборів, фінансування наукових розробок, а також вироблення освітньої та кадрової політики для забезпечення потреб нового інноваційного простору. Комплекс заходів по підготовці до переходу економіки на новий технологічний уклад вимагає координації учасників виробничого процесу та носіїв інновацій, концентрації достатнього обсягу ресурсів (фінансових, трудових тощо), створення умов для ефективізації капіталу в науці і освіті та налагодження взаємодії бізнесу та науки, що забезпечить створення проривних технологій та модернізацію існуючих. 
Існує думка, що у більшості промислових компаній світу інвестиції в технології зростають швидше, ніж доходи i, в багатьох випадках, швидше, ніж ВВП будь-якої країни, що засвідчує їх драйверну природу та довгостроковість дії.

Висновки та перспективи подальших досліджень. Результати проведено дослідження засвідчують про нарощення інноваційного потенціалу країн-членів ЄС впродовж 2010, 2019 рр. Дещо нижчий рівень інноваційного розвитку прослідковується в нових країнах-членах ЄС. Країни-члени ЄC і надалі займають високі рейтингові позиції за індексом інноваційного розвитку у світі та посилюють свої позиції у світі.

Слід наголосити i на тому, що концепція інклюзивної розвитку економіки, активно розвивається в країнах-членах $Є С$ протягом останніх років. Основний акцент в сучасній політиці $Є \mathrm{C}$ робиться на інновації, які зумовлють структурні зміни в економіці, і як наслідок - виграш від зростання приносить користь різним групам суспільства, збільшення доходу та добробуту в довгостроковій перспективі. Інновації мають безпосередній вплив на вирішення проблеми нерівності доходів через створення нових конкурентоспроможних робочих місць. Однак, разом з тим, інновації не обов'язково впливають на дохід всіх категорій населення однаково. Більше того, інноваційна політика в СС відіграє визначальну роль у формуванні економіки знань а отже, у розподілі винагород та збитків серед різних груп у суспільстві. Інструменти її реалізації спрямовані на усунення бар'єрів, для участі в інноваційній діяльності усіх соціальних груп населення, фірм та окремих територій.

\section{ЛITEРАТУРА}

1. Global Innovation Index. URL: http://statisticstimes.com/ranking/global-innovation-index.php

2. World Innovation Report. The Economist URL: http://www.economist.com.

3. Офіційний сайт Організації економічного співробітництва i розвитку. URL: http://www.oecd.org.

4. Science, Research and Innovation Performance of the EU 2018 Strengthening the foundations for Europe's future. URL: https://ec.europa.eu/info/sites/info/files/srip-report-full_2018_en.pdf

5. High-tech statistics. Eurostat. 2017. URL: http://ec.europa.eu/eurostat/statisticsexplained/index.php/High-tech_statistics-economic_data

6. Commodity Indexes for the Standard International Trade Classification, Revision 3. URL: https://unstats.un.org/unsd/tradekb/Knowledgebase/50096/Commodity-Indexes-for-the-StandardInternational-Trade-Classification-Revision-3]/

7. Production and international trade in high-tech products. URL: https://ec.europa.eu/eurostat/statistics-explained/index.php/Production_and_international_trade_in_hightech_products.

8. Смаль В.В. Високотехнологічний експорт: просторово-статистичний аналіз на прикладі країн Європейського Союзу. URL: http://nbuv.gov.ua/UJRN/gt_2010_10_16.

9. Science, Research and Innovation Performance of the EU 2018. URL: https://ec.europa.eu/info/sites/info/files/srip/rec-17-015_srip-brochureb5_en_v10_outec_20180412.pdf

10. Eurostast. URL: https://ec.europa.eu/eurostat/

11. Бабич Т.О. Економічні детермінанти зміни технологічних укладів. Актуальні проблеми міжнародних відносин. Випуск 126. Ч. І. 2015. С. 167-179.

12. Ксенофонтова О.Л. Опыт зарубежных стран по созданию и функционированию кластеров: модельный подход. URL: https://www.isuct.ru/e-publ/snt/sites/ru.e-publ.snt/files/2015/02/snt_2015_n02036.pdf

\section{REFERENCES}

1. Global Innovation Index. Retrieved from http://statisticstimes.com/ranking/global-innovationindex.php [in English].

2. World Innovation Report. The Economist Retrieved from http://www.economist.com. [in English].

3. Офіційний сайт Організації економічного співробітництва i розвитку. Retrieved from http://www.oecd.org. [in English].

4. Science, Research and Innovation Performance of the EU 2018 Strengthening the foundations for Europe's future. Retrieved from https://ec.europa.eu/info/sites/info/files/srip-report-full_2018_en.pdf [in English].

5. High-tech statistics. Eurostat. 2017. Retrieved from http://ec.europa.eu/eurostat/statisticsexplained/index.php/High-tech_statistics-economic_data [in English]. 
6. Commodity Indexes for the Standard International Trade Classification, Revision 3. Retrieved from https://unstats.un.org/unsd/tradekb/Knowledgebase/50096/Commodity-Indexes-for-the-Standard-

International-Trade-Classification-Revision-3] [in English].

7. Production and international trade in high-tech products. Retrieved from https://ec.europa.eu/eurostat/statistics-explained/index.php/Production_and_international_trade_in_hightech_products [in English].

8. Smal, V.V. (2016). Vysokotekhnolohichnyi eksport: prostorovo-statystychnyi analiz na prykladi krain Yevropeiskoho Soiuzu [High-tech exports: spatial and statistical analysis on the example of the European Union]. Retrieved from http://nbuv.gov.ua/UJRN/gt_2010_10_16. [in Ukrainian].

9. Science, Research and Innovation Performance of the EU 2018. Retrieved from https://ec.europa.eu/info/sites/info/files/srip/rec-17-015_srip-brochureb5_en_v10_outec_20180412.pdf [in English].

10. Eurostast. Retrieved from https://ec.europa.eu/eurostat/ [in English].

11. Babych, T.O. (2015). Ekonomichni determinanty zminy tekhnolohichnykh ukladiv [Economic determinants of changes in technological systems]. Aktualni problemy mizhnarodnykh vidnosyn - Current issues of international relations, Vol. 126: I, 167-179. [in Ukrainian].

12. Ksenofontova, O.L.(2015). Oput zarubezhnukh stran po sozdanyiu y funktsyonyrovanyiu klasterov: modelnui podkhod [The experience of foreign countries in the creation and functioning of clusters: a model approach]. Retrieved from https://www.isuct.ru/e-pub1/snt/sites/ru.epubl.snt/files/2015/02/snt_2015_n02-036.pdf [in Russian]. 